\title{
TWO DISTINC'T SOLUBILIZED BENZODIAZEPINE RECEPTORS: DIFFERENTIAL MODULATION BY IONS ${ }^{1}$
}

\author{
MATHEW M. S. LO AND SOLOMON H. SNYDER ${ }^{2}$ \\ Departments of Neuroscience, Pharmacology and Experimental Therapeutics, and Psychiatry and Behavioral Sciences, Johns \\ Hopkins University School of Medicine, Baltimore, Maryland 21205
}

Received January 3, 1983; Revised May 9, 1983; Accepted May 9, 1983

\begin{abstract}
The modulation of solubilized type 1 and type 2 benzodiazepine receptors from cow brain by $\gamma$ aminobutyric acid (GABA), divalent cations, and anions has been evaluated. GABA stimulates $\left[{ }^{3} \mathrm{H}\right]$ flunitrazepam binding of both receptor subtypes, whereas divalent cations and anions selectively stimulate solubilized type 2 receptors. Of numerous anions examined, only chloride, bromide, and iodide enhance $\left[{ }^{3} \mathrm{H}\right]$ flunitrazepam binding. Chloride and bromide increase mainly receptor affinity for $\left[{ }^{3} \mathrm{H}\right]$ flunitrazepam, whereas iodide largely influences $B_{\max }$ values. Divalent cations also stimulate soluble type 2 receptors. Calcium, zinc, manganese, barium, and magnesium have similar potencies in enhancing $\left[{ }^{3} \mathrm{H}\right]$ flunitrazepam binding, whereas copper and nickel are about 4 to 5 times more potent. The 2- to 3 -fold increase in type 2 receptor binding by divalent cations involves change in numbers of binding sites. Effects of combinations of GABA, calcium, and chloride suggest that they may exert their modulating effects on type 2 receptors through different mechanisms. GABA, calcium, and chloride also protect $\left[{ }^{3} \mathrm{H}\right]$ flunitrazepam binding from heat inactivation, indicating a close link in the native state between the GABA, ions, and the benzodiazepine recognition sites. Since physiologic concentrations of calcium and chloride influence type 2 receptors, these ions may be involved in those pharmacologic effects of benzodiazepines mediated by type 2 sites.
\end{abstract}

The ionic modulation of neurotransmitter receptorbinding sites in some instances may relate to the synaptic actions of the transmitters. Anionic effects on strychnine binding associated with glycine receptors (Young and Snyder, 1974; Muller and Snyder, 1978) correlate with the ability of the ions to reverse inhibitory postsynaptic potentials, suggesting a linkage of the glycine receptorbinding sites to chloride ion channels. Anionic modulation of $\gamma$-aminobutyric acid (GABA) receptors has also been described (Enna and Snyder, 1977). Similarly, divalent cations also enhance agonist binding to a number of receptors-for example, biogenic amine and opiate receptors (Bird and Maguire, 1978; Williams et al., 1978; Snyder and Goodman, 1980).

Benzodiazepine receptors are also influenced by ions. Anions stimulate benzodiazepine receptor binding to brain membranes (Martin and Candy, 1978, Costa et al., 1979). Their relative potencies in enhancing benzodiazepine receptor binding parallel somewhat their ability to

\footnotetext{
${ }^{1}$ Supported by United States Public Health Service Grants DA00266, MH-18501, and NS-16375, a grant from the McKnight Foundation, and Research Scientist Award DA-00074 to S. H. S. We thank Greg Mack for excellent technical assistance and Nancy Bruce for manuscript preparation.

${ }^{2}$ To whom correspondence should be addressed.
}

penetrate activated synaptic chloride ion channels in motor neurons (Costa et al., 1979). Anions are also required for the barbiturate enhancement of benzodiazepine binding (Leeb-Lundberg et al., 1980; Asno and Ogasawara, 1981). In one initial report, benzodiazepine binding was also stimulated by some divalent cations (Mackerer and Kochman, 1978).

Pharmacologic data have suggested the existence of at least two subtypes of benzodiazepine receptor which vary in their distribution in different brain regions (Squires et al., 1978; Klepner et al., 1979; Nielsen and Braestrup, 1980; Sieghart and Karobath, 1980; Ehlert et al., 1981). We have obtained direct evidence for two benzodiazepine receptor subtypes based on differential solubilization from brain membranes (Lo et al., 1982a). The drug specificity and regional distribution of these two types correspond to the type 1 and type 2 receptor subtypes suggested by pharmacologic data. More recently, we have shown by light microscopic autoradiography that the differential distribution of detergent-insensitive and -sensitive receptors corresponds closely to the respective variations in distribution of type 1 and type 2 receptors defined on pharmacologic grounds (Lo et al., 1983).

In a preliminary report we showed that solubilized type 2 benzodiazepine receptors are stimulated by chloride and calcium, whereas type 1 sites are unaffected (Lo 
et al., 1982b). In the present study we have explored in detail the differential modulation by anions and divalent cations of solubilized type 1 and type 2 benzodiazepine receptors and their interaction with the modulation by GABA.

\section{Materials and Methods}

$\left[{ }^{3} \mathrm{H}\right]$ Flunitrazepam $\left(\left[{ }^{3} \mathrm{H}\right] \mathrm{FNZ}\right)$ was obtained from New England Nuclear. Benzodiazepines were gifts from W. Scott (Hoffmann-La Roche). All other chemicals were from commercial sources. Fresh cow brains were obtained locally and were used immediately or frozen and stored at $-70^{\circ} \mathrm{C}$.

Solubilization of type 1 and type 2 benzodiazepine receptors. Cow brain was homogenized at $0^{\circ} \mathrm{C}$ in $10 \mathrm{vol}$ of $50 \mathrm{~mm}$ phosphate buffer $\left(\mathrm{KH}_{2} \mathrm{PO}_{4}\right), \mathrm{pH} 7,10 \mathrm{mM} \mathrm{Na}$ EDTA, $0.1 \mathrm{mM}$ phenylmethylsulfonyl fluoride containing $50 \mu \mathrm{g}$ of bacitracin, $5 \mu \mathrm{g}$ of soybean trypsin inhibitor, and $5 \mu \mathrm{g}$ of leupeptin $/ \mathrm{ml}$, and centrifuged at $50,000 \times g$ for $15 \mathrm{~min}$. Pellets were extracted twice in 2 vol of the homogenizing buffer containing $2 \%$ sodium cholate for $40 \mathrm{~min}$ at $4^{\circ} \mathrm{C}$ and centrifuged at $150,000 \times \mathrm{g}$ for $1 \mathrm{hr}$. Supernatants for both extractions were pooled. A buffy soft pellet was removed by resuspension in $20 \mathrm{vol}$ of homogenizing buffer and centrifugation at $50,000 \times g$ for $10 \mathrm{~min}$. The insoluble hard pellet was extracted in $2 \mathrm{vol}$ of homogenizing buffer containing $2 \%$ sodium cholate plus $1 \mathrm{M} \mathrm{NaCl}$ for $40 \mathrm{~min}$ at $4^{\circ} \mathrm{C}$ and centrifuged at $150,000 \times g$ for $30 \mathrm{~min}$. Detergent-soluble (type 2) and detergent plus salt-soluble (type 1 ) extracts were dialyzed against $2 \times 8$ liters of $\mathrm{H}_{2} \mathrm{O}$ for $2 \mathrm{hr}$ and $15 \mathrm{hr}$ in $25 \mathrm{~mm}$ phosphate buffer $(\mathrm{pH} 7), 0.01 \%$ sodium cholate at $4^{\circ} \mathrm{C}$.

Receptor assay. The binding of $\left[{ }^{3} \mathrm{H}\right] \mathrm{FNZ}$ was measured using the polyethylene glycol $/ \gamma$-globulin precipitation method (Gavish et al., 1979; Gavish and Snyder, 1981). Soluble receptor fractions extracted from 50 to $100 \mathrm{mg} /$ $\mathrm{ml}$ of original tissue were incubated with $0.8 \mathrm{nM}\left[{ }^{3} \mathrm{H}\right]$ FNZ at $0^{\circ} \mathrm{C}$ for $1 \mathrm{hr}$ in a volume of $0.5 \mathrm{ml}$ and precipitated by the addition of $0.1 \mathrm{ml}$ of $\gamma$-globulin $(10 \mathrm{mg} / \mathrm{ml})$ and $0.2 \mathrm{ml}$ of polyethylene glycol $(30 \% \mathrm{w} / \mathrm{v})$, followed by washing with $3 \times 3 \mathrm{ml}$ of $8.5 \%$ polyethylene glycol over Whatman GF/B filters. Nonspecific binding was determined in the presence of $1 \mu \mathrm{M}$ FNZ. Total and nonspecifically bound radioactivities were typically 3000 and $200 \mathrm{cpm}$, respectively. Ion concentration of up to $0.25 \mathrm{M}$ $\mathrm{NaCl}$ did not affect nonspecific binding.

An alternative assay to quantify receptors uses concanavalin A-Sepharose (Lo et al., 1982a). In this assay, receptor extracts (without dialysis) were allowed to react with concanavalin A-Sepharose $(1 \mathrm{ml}$ of extract/10 mg of concanavalin $\mathrm{A} / \mathrm{ml}$ of packed resin) for 2 to $3 \mathrm{hr}$ or overnight, at $4^{\circ} \mathrm{C}$. The resin was washed with 100 to 200 vol of $25 \mathrm{~mm}$ phosphate buffer $(\mathrm{pH} 7.0), 0.01 \%$ sodium cholate and resuspended to 5 vol of the original extract. Aliquots of the receptor-Sepharose suspension were incubated with $\left[{ }^{3} \mathrm{H}\right] \mathrm{FNZ}$ at $0^{\circ} \mathrm{C}$ for $1 \mathrm{hr}$ and filtered over Whatman GF/B filters followed by three washes with 3 $\mathrm{ml}$ of $25 \mathrm{~mm}$ phosphate buffer $(\mathrm{pH} 7)$.

\section{Results}

Receptor solubilization and receptor-binding assay. We have shown previously that extraction of crude brain membranes with various detergents solubilizes type 2 benzodiazepine receptor sites, whereas type 1 sites resist detergent solubilization (Lo et al., 1982a). The insoluble receptor sites can be recovered in solution by extraction with $1 \mathrm{M} \mathrm{NaCl}$ plus detergent. In order to remove endogenous GABA, high detergent, and salt concentrations which would otherwise interfere with receptor-binding activity, soluble receptor extracts were extensively dialyzed against deionized water, then against phosphate buffer containing $0.01 \%$ sodium cholate. Typically, some precipitates are noticeable after storage for $6 \mathrm{hr}$ and especially in the high salt plus detergent extracts. However, receptor-binding activity remains in solution as determined by centrifugation at $150,000 \times g$ for $1 \mathrm{hr}$. Since the particulate material did not interfere with the polyethylene glycol precipitation assay, soluble type 1 and type 2 receptor extracts were not further processed. The electrical conductance of type 1 and type 2 receptor extracts after dialysis are routinely measured to ensure similar ionic conditions for the receptor extracts and to check for the complete removal of salt. In some experiments, $1 \mathrm{M} \mathrm{NaCl}$ was added to detergent (type 2 receptor) extracts and dialyzed with the salt plus detergent extracts. In these cases, the modulation by GABA and differential ionic effects on type 2 receptors were unaffected. Hence, dialysis of the receptor extracts is able to reduce salt concentrations which would otherwise inhibit anion modulation of type 2 receptors.

Anion modulation of soluble type 1 and type 2 benzodiazepine receptors. Chloride ions enhance $\left[{ }^{3} \mathrm{H}\right] \mathrm{FNZ}$ binding to type 2 but not type 1 soluble benzodiazepine receptors when assayed either with the precipitation method or by immobilization onto concanavalin A-Sepharose (Fig. 1 and Table I). The enhancement of binding by $0.1 \mathrm{M}$ chloride of about $50 \%$ to soluble type 2 receptors resembles what we previously reported for a crude preparation of Triton X-100-solubilized benzodiazepine receptors (Gavish and Snyder, 1981) as well as results with washed membrane preparations (Table II). The same extent of enhancement occurs with sodium or ammonium salts of chloride (Table I) or with potassium or lithium salts (data not shown). By contrast, no stimulation of $\left[{ }^{3} \mathrm{H}\right] \mathrm{FNZ}$ binding to solubilized type 1 receptors is observed at any concentration of chloride (Table I and Fig. 1).

The relative influence of different ions on glycine (Young and Snyder, 1974) and benzodiazepine (Costa et al., 1979) binding in membranes has suggested a similarity of the anion recognition site to the chloride channel. To evaluate such a relationship with solubilized benzodiazepine receptors, we evaluated a series of 14 anions and their sodium or ammonium salts (Table I). None of the anions stimulate $\left[{ }^{3} \mathrm{H}\right] \mathrm{FNZ}$ binding to type 1 receptors. By contrast, chloride and bromide augment binding to type 2 receptors by about $50 \%$, whereas iodide has a lesser effect. No other anions examined increased type 2 receptor binding. The anion specificity of soluble type 2 receptors observed in this study clearly does not agree with the specificity for enhancement of benzodiazepine binding (Costa et al., 1979) or barbiturate interactions (Leeb-Lundberg et al., 1980; Asno and Ogasawara, 1981) in membrane fragments.

Interestingly, some anions reduce binding. For example, maleate lowers binding by 30 to $50 \%$ of both of type 


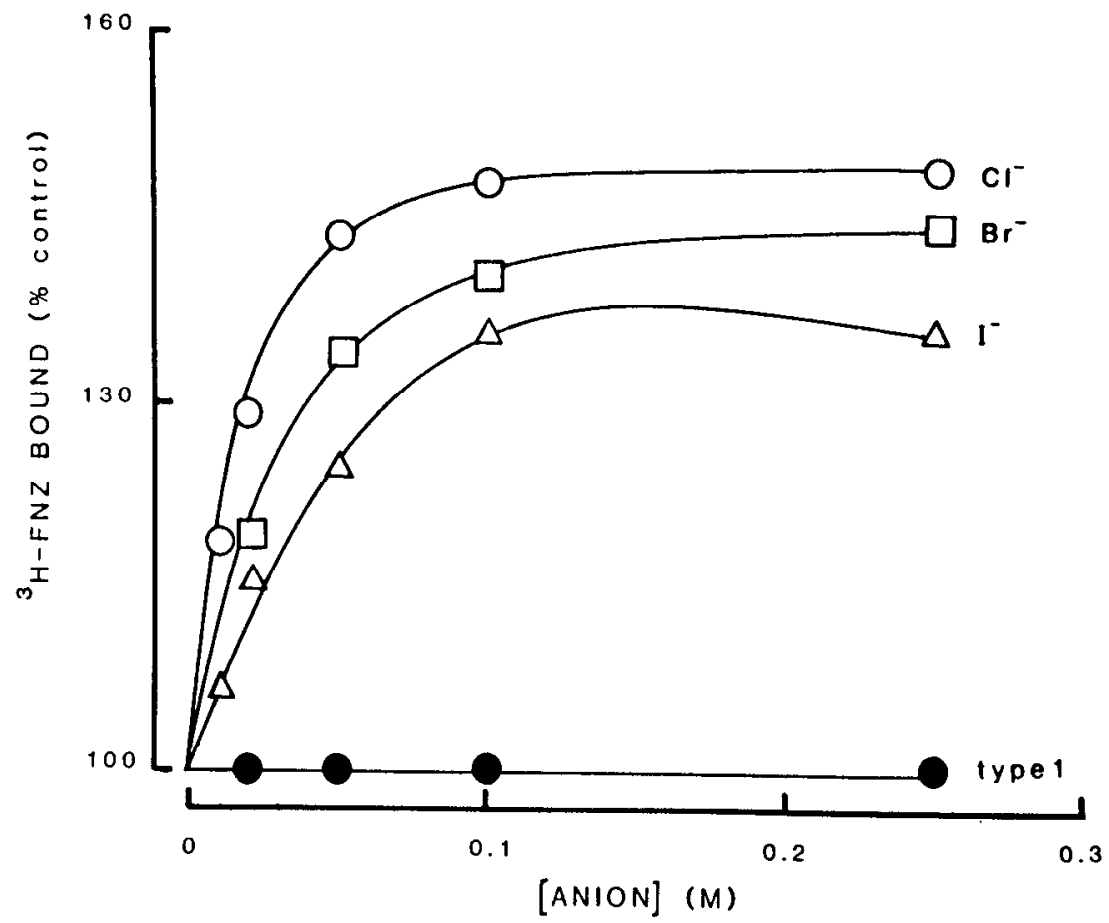

Figure 1. Anion modulation of soluble type 1 and type 2 benzodiazepine receptors. Soluble receptor extract was prepared from cow cerebral cortex by differential solubilization as described under "Materials and Methods." $\left[{ }^{3} \mathrm{H}\right] \mathrm{FNZ}$ binding in the presence of increasing concentrations of $\mathrm{NaCl}(\mathrm{O}), \mathrm{NaBr}(\square)$, or $\mathrm{NaI}(\triangle)$ was measured by incubation with $0.8 \mathrm{nM}\left\lfloor^{3} \mathrm{H}\right\rfloor \mathrm{FNZ}$ in $25 \mathrm{mM}$ $\mathrm{KPO}_{4}\left(\mathrm{pH} \mathrm{7.0)}, 0.01 \%\right.$ sodium cholate for $1 \mathrm{hr}$ at $0^{\circ} \mathrm{C}$. As shown for $\mathrm{NaCl}$ only (O), $\left[{ }^{3} \mathrm{H}\right] \mathrm{FNZ}$ binding to type 1 receptors $(0)$ in the presence of $\mathrm{NaCl}, \mathrm{NaBr}$, and $\mathrm{NaI}$ did not differ from control values. The experiment was replicated four times with variations less than $10 \%$.

\section{TABLE I}

Anion modulation of soluble type 1 and type 2 benzodiazepine receptors

Solubilized type 1 and type 2 receptors were incubated in the presence or absence of the anions $\left(\mathrm{Na}\right.$ or $\mathrm{NH}_{4}$ salts) with $0.8 \mathrm{nM}\left[{ }^{3} \mathrm{H}\right]$ FNZ in $25 \mathrm{~mm}$ phosphate buffer $(\mathrm{pH} 7.0), 0.01 \%$ cholate at $0^{\circ} \mathrm{C}$ for 1 $\mathrm{hr}$ and assayed by precipitation with $\gamma$-globulin and polyethylene glycol or by immobilization to concanavalin A-Sepharose (see "Materials and Methods"). Means ( \pm SEM) of four to six separate determinations are shown.

\begin{tabular}{lcc}
\hline \multirow{2}{*}{ Anions } & \multicolumn{2}{c}{$\left[{ }^{3} \mathrm{H}\right] \mathrm{FNZ}$ Bound (\% Control) } \\
\cline { 2 - 3 } & Type 2 & Type 1 \\
\hline $\mathrm{Cl}^{-}$ & $145 \pm 5^{a}$ & $101 \pm 2$ \\
$\mathrm{Br}^{-}$ & $142 \pm 4^{a}$ & $106 \pm 8$ \\
$\mathrm{I}^{-}$ & $126 \pm 12^{a}$ & $100 \pm 4$ \\
$\mathrm{~F}^{-}$ & $115 \pm 14$ & $106 \pm 8$ \\
$\mathrm{ClO}_{4}^{-}$ & $70 \pm 14$ & $99 \pm 10$ \\
$\mathrm{NO}_{4}^{-}$ & $96 \pm 8$ & $101 \pm 8$ \\
$\mathrm{SCN}^{-}$ & $100 \pm 2$ & $72 \pm 3$ \\
Acetate & $104 \pm 5$ & $99 \pm 1$ \\
Formate & $92 \pm 18$ & $92 \pm 9$ \\
Oxalate & $101 \pm 11$ & $104 \pm 5$ \\
Tartrate & $104 \pm 12$ & $95 \pm 9$ \\
Maleate & $69 \pm 4$ & $50 \pm 7$ \\
SO & & $92 \pm 5$ \\
$\mathrm{~N}_{3}^{-}$ & $91 \pm 4$ & $99 \pm 7$ \\
\hline
\end{tabular}

${ }^{a} p<0.01$ for difference from control values.

1 and type 2 receptors, while perchlorate decreases binding by about $30 \%$ to type 2 but not type 1 receptors. Since all experiments herein use anion salts adjusted to $\mathrm{pH} 7$, observed changes in binding are not due to altered $\mathrm{pH}$.
TABLE II

Effects of chloride on total benzodiazepine receptor binding in native hippocampal membrane and its differential effects on type 1 and type 2 sites calculated by displacement with $0.2 \mu \mathrm{M}$ CL218872

Binding was assayed as described in the text with or without $0.1 \mathrm{M}$ $\mathrm{NaCl}$. $\left[{ }^{3} \mathrm{H}\right] \mathrm{FNZ}$ binding to control or in the presence of $0.2 \mu \mathrm{M}$ CL218872 was experimentally determined. The amount of $\left[{ }^{3} \mathrm{H}\right] \mathrm{FNZ}$ bound to type 1 and type 2 receptors was calculated as follows: affinities of CL218872 for type 1 and type 2 receptors are $20 \mathrm{nM}$ and $1000 \mathrm{nM}$, respectively (Klepner et al., 1979; Niehoff et al., 1982). Therefore, in the presence of $0.2 \mu \mathrm{M}$ CL218872 and $0.8 \mathrm{nM}\left[{ }^{3} \mathrm{H}\right] \mathrm{FNZ}, 83 \%$ and $10 \%$ of $\left[{ }^{3} \mathrm{H}\right] \mathrm{FNZ}$ binding are displaced from type 1 and type 2 sites, respectively. Values shown are means from three experiments which varied less than $20 \%$.

\begin{tabular}{lcccc}
\hline & \multicolumn{4}{c}{$\left[{ }^{3} \mathrm{H}\right]$ FNZ Bound (specific cpm) } \\
\cline { 2 - 5 } & Total & +CL218872 & Type 1 & Type 2 \\
\hline Control & 3344 & 2291 & 1233 & 2112 \\
$0.1 \mathrm{M} \mathrm{Cl}^{-}$ & 3860 & 2905 & 1110 & 2779 \\
\hline
\end{tabular}

The enhancement of type 2 receptor binding by chloride, bromide, and iodide is maximal (about $150 \%$ of control) at about $0.1 \mathrm{M}$ concentration with half-maximal effects for chloride, bromide, and iodide at 10, 22, and 30 $\mathrm{mM}$, respectively (Fig. 1). Saturation analysis of various concentrations of $\left[{ }^{3} \mathrm{H}\right] \mathrm{FNZ}$ indicates that the stimulation of binding to type 2 receptors by chloride and bromide involves an enhancement of affinity with a lesser effect on numbers of binding sites ( $B_{\max }$ ) (Fig. 2 and Table III). On the other hand, the lesser augmentation of binding by iodide appears to involve mainly an increase in $B_{\max }$ with a slight reduction in affinity. 


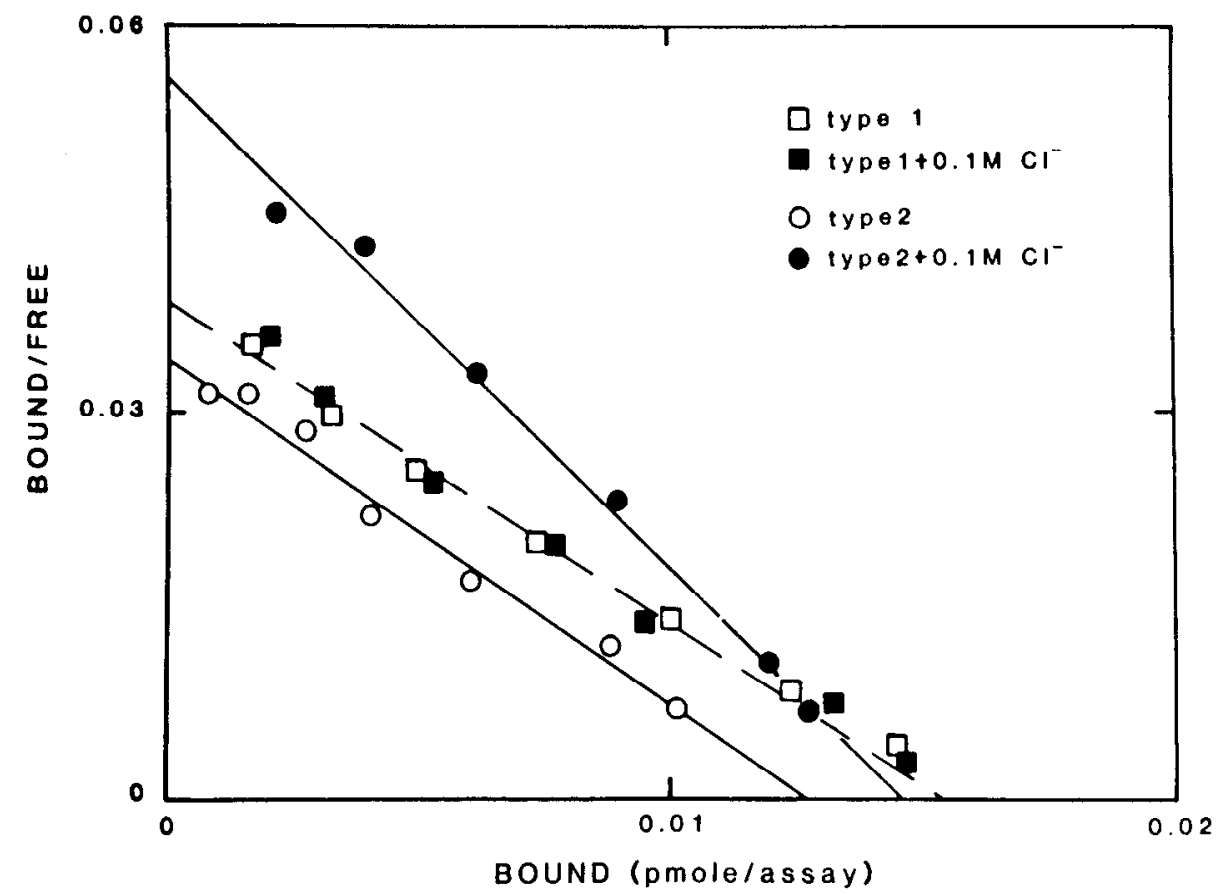

Figure 2. Chloride modulation of soluble type 1 and type 2 benzodiazepine receptors. Soluble type 1 and type 2 receptors were incubated with increasing concentrations of $\left[{ }^{3} \mathrm{H}\right] \mathrm{FNZ}$ in the presence or absence of $0.1 \mathrm{M} \mathrm{NaCl}$ for $1 \mathrm{hr}$ at $0^{\circ} \mathrm{C}$. Bound ligand was precipitated by adding polyethylene glycol and $\gamma$-globulin and filtered over Whatman GF/B filters. The data are shown as a Scatchard transformation. The expcriment was replicated three times with variations less than $20 \%$.

TABLE III

Anion modulation of soluble type 2 benzodiazepine receptor

Saturation binding analysis to soluble type 2 receptors in the absence or presence of $0.1 \mathrm{M}$ halide salts was performed at $0^{\circ} \mathrm{C}$ as described in the legend to Figure 2. Affinities $\left(K_{D}\right)$ and the number of sites $\left(B_{\max }\right)$ were calculated by least square fit to Scatchard plots. Values shown are the mean $( \pm \mathrm{SEM})$ of five separate determinations using nine ligand concentrations.

\begin{tabular}{ccc}
\hline Anion & $K_{D}$ & $B_{\max }$ \\
\hline & $n M$ & pmol/gm tissue \\
Control & $0.94 \pm 0.04$ & $1.05 \pm 0.01$ \\
$0.1 \mathrm{M} \mathrm{Cl}^{-}$ & $0.66 \pm 0.04^{a}$ & $1.26 \pm 0.05^{b}$ \\
$0.1 \mathrm{M} \mathrm{Br}^{-}$ & $0.67 \pm 0.01^{a}$ & $1.19 \pm 0.05^{b}$ \\
$0.1 \mathrm{M} \mathrm{I}^{-}$ & $1.24 \pm 0.02^{b}$ & $1.50 \pm 0.05^{a}$ \\
\hline
\end{tabular}

${ }^{a} p<0.005$ as compared to control values.

${ }^{b} p<0.01$ as compared to control values.

We have also analyzed chloride stimulation of $\left[{ }^{3} \mathrm{H}\right]$ FNZ binding in washed native membranes in the presence or absence of $0.2 \mu \mathrm{M}$ CL218872. Under such conditions, the respective binding to type 1 and type 2 sites can be calculated from the affinities of CL218872 for the two receptors, the concentration of $\left[{ }^{3} \mathrm{H}\right] \mathrm{FNZ}$ used in the assay, and the affinities of benzodiazepine receptors for $\left[{ }^{3} \mathrm{H}\right] \mathrm{FNZ}$ in the presence or absence of added GABA. This method is described in full detail elsewhere (Lo et al., 1983). The total increase in $\left[{ }^{3} \mathrm{H}\right] \mathrm{FNZ}$ binding to native membrane thus evaluated is attributable fully to type 2 receptors (Fig. 3) even in the membrane-bound state. This finding is in agreement with above results on solubilized type 2 receptors.

Modulation of soluble benzodiazepine receptors by divalent cations. In an initial report Mackerer and Kochman (1978) found that some divalent cations could enhance benzodiazepine binding in rat brain membranes, although the membranes were not treated with chelating agents to remove endogenous divalent cations. We prepared and solubilized membranes with EDTA to remove endogenous divalent cations and GABA prior to solubilization followed by extensive dialysis to remove the chelating agent. Under these conditions substantial stimulation of $\left[{ }^{3} \mathrm{H}\right] \mathrm{FNZ}$ binding by divalent cations to type 2 solubilized receptors is observed (Fig. 4 and Table IV). Some enhanced binding is detected with as little as 0.2 mM calcium chloride with maximal effects at $5 \mathrm{mM}$. The stimulation by calcium is blocked entirely by treatment with equimolar amounts of EGTA. In marked contrast, no augmentation of $\left[{ }^{3} \mathrm{H}\right] \mathrm{FNZ}$ binding to type 1 solubilized receptors occurs with any divalent cations tested.

Unlike the effect of chloride, the stimulation of $\left[{ }^{3} \mathrm{H}\right]$ FNZ binding to type 2 receptors by calcium involves an increased number of binding sites with no effect on $K_{D}$ (Fig. 4). These results differ from those of Mackerer and Kochman (1978) who, using intact membranes, reported that nickel increased benzodiazepine affinity rather than numbers of sites.

The stimulation of type 2 receptor binding by calcium is apparent with a variety of divalent cations (Table IV). Maximal enhancement to about 220 to $260 \%$ of control levels is similar for most of the divalent cations. Copper and nickel are the most potent divalent cations, producing half-maximal stimulation at about $0.2 \mathrm{~mm}$, about 5 times more potent than calcium.

Interactions between $G \Lambda B \Lambda$, divalent cation, and anion in modulation of solubilized type 2 benzodiazepine receptor. To ascertain whether GABA, anions, and divalent cations influence type 2 benzodiazepine receptor binding at similar or disparate sites, we evaluated interactions between them (Figs. 5 and 6 ). In the presence of chloride, 


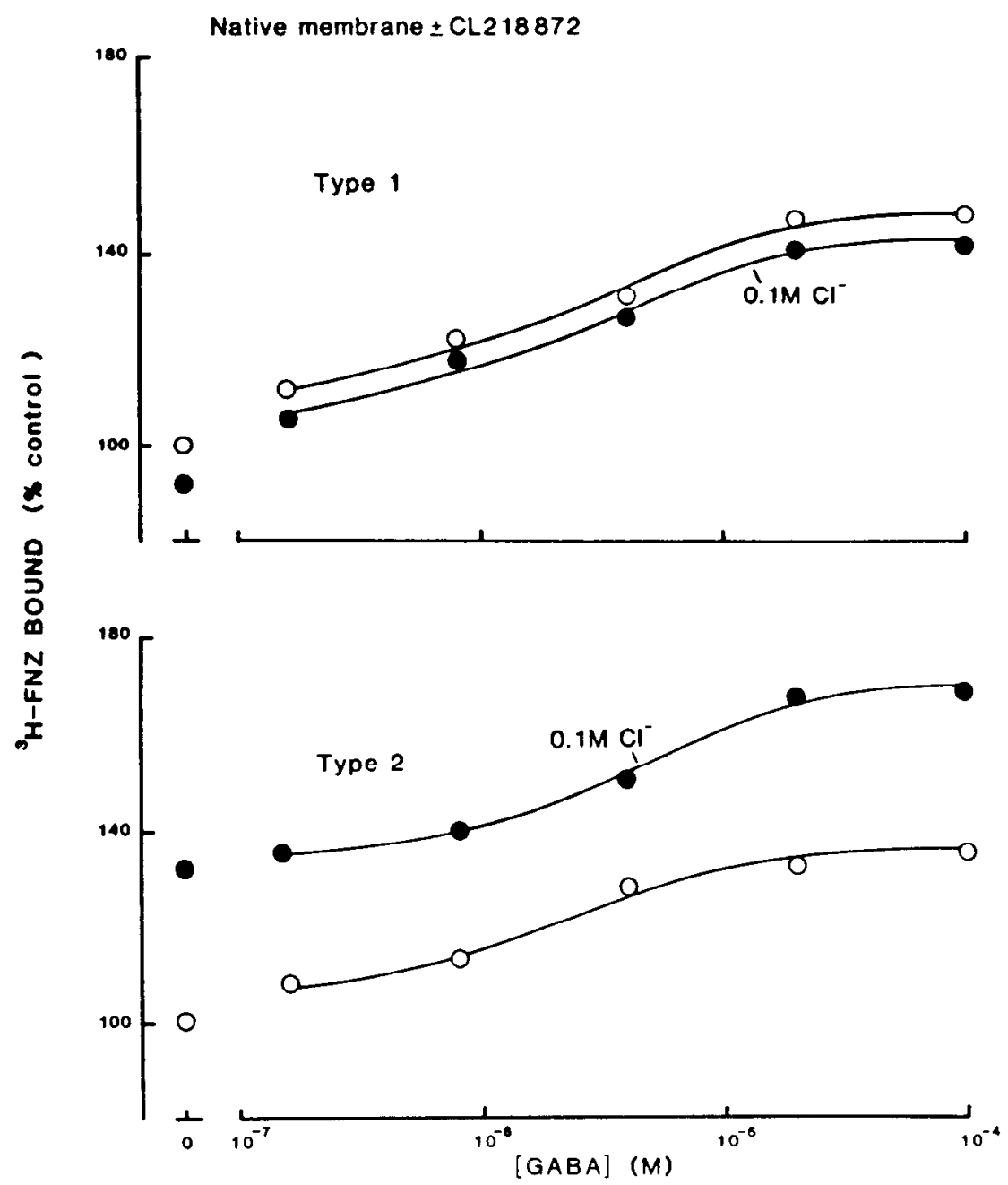

Figure 3. Chloride modulation of benzodiazepine receptors in native membranes. In this experiment binding was performed in the presence or absence of $0.2 \mu \mathrm{M}$ CL218872 with $1.17 \mathrm{nM}\left[{ }^{3} \mathrm{H}\right] \mathrm{FNZ}$. Assuming $K_{D}$ values of 20 and $1000 \mathrm{nM}$ for CL218872 at type 1 and type 2, respectively, $24.5 \%$ and $94.2 \%$ of $\left[{ }^{3} \mathrm{H}\right] \mathrm{FNZ}$ binding to type 1 and type 2 sites, respectively, are displaced by $0.2 \mu \mathrm{M}$ CL218872. The open circles designate control values and the solid circles indicate samples with $0.1 \mathrm{M} \mathrm{NaCl}$. The experiment was replicated three times with variations less than $20 \%$.

calcium is still able to stimulate $\left[{ }^{3} \mathrm{H}\right] \mathrm{FNZ}$ binding (Fig. 5). The ability of calcium to augment chloride enhancement diminishes with increasing concentration of calcium. In other words, the dose response of calcium enhancement in type 2 receptor binding appears to be shallower in the presence than in the absence of chloride ions. Furthermore, calcium enhances $\left[{ }^{3} \mathrm{H}\right] \mathrm{FNZ}$ binding by increasing the $B_{\max }$, whereas chloride stimulation involves an increase both in affinity and $B_{\max }$. This indicates that anions and divalent cations do not exert their actions through the same mechanism or a similar site. However, anions and divalent cations interact in a complex manner in modulating type 2 receptors.

GABA modulation of benzodiazepine receptors differs markedly from that of chloride and divalent cations in that GABA stimulates $\left[{ }^{3} \mathrm{H}\right] \mathrm{FNZ}$ binding to type 1 receptors with the same potency and to the same extent as is observed with type 2 receptors (Fig. 3). This observation also confirms our earlier study of solubilized type 1 and type 2 receptors in which we showed that GABA in-
TABLE IV

Cation stimulation of soluble type 2 benzodiazepine receptor

Soluble type 2 receptors prepared from cow cerebral cortex were incubated with $0.8 \mathrm{nM}\left[{ }^{3} \mathrm{H}\right] \mathrm{FNZ}$ in the absence or presence of eight concentrations of cations. Values of maximal stimulation $\left(E_{\max }\right)$ and the cation concentration giving $50 \%$ stimulation $\left(\mathrm{ED}_{50}\right)$ shown are the means of three separate experiments which varied less than $20 \%$.

\begin{tabular}{lcc}
\hline Cations & $\mathrm{ED}_{50}(\mathrm{mM})$ & $E_{\max }(\%$ Control $)$ \\
\hline $\mathrm{Cu}^{2+}$ & 0.18 & 260 \\
$\mathrm{Ni}^{2+}$ & 0.20 & 230 \\
$\mathrm{Co}^{2+}$ & 0.50 & 250 \\
$\mathrm{Zn}^{2+}$ & 0.87 & 256 \\
$\mathrm{Mn}^{2+}$ & 0.88 & 240 \\
$\mathrm{Ca}^{2+}$ & 0.90 & 225 \\
$\mathrm{Ba}^{2+}$ & 1.00 & 248 \\
$\mathrm{Mg}^{2+}$ & 1.10 & 230 \\
\hline
\end{tabular}

creases the affinity for benzodiazepine of both solubilized type 1 and type 2 receptors (Lo et al., 1982b). In contrast, calcium enhances type 2 receptor binding by increasing the number of binding sites. This clearly indicates that 


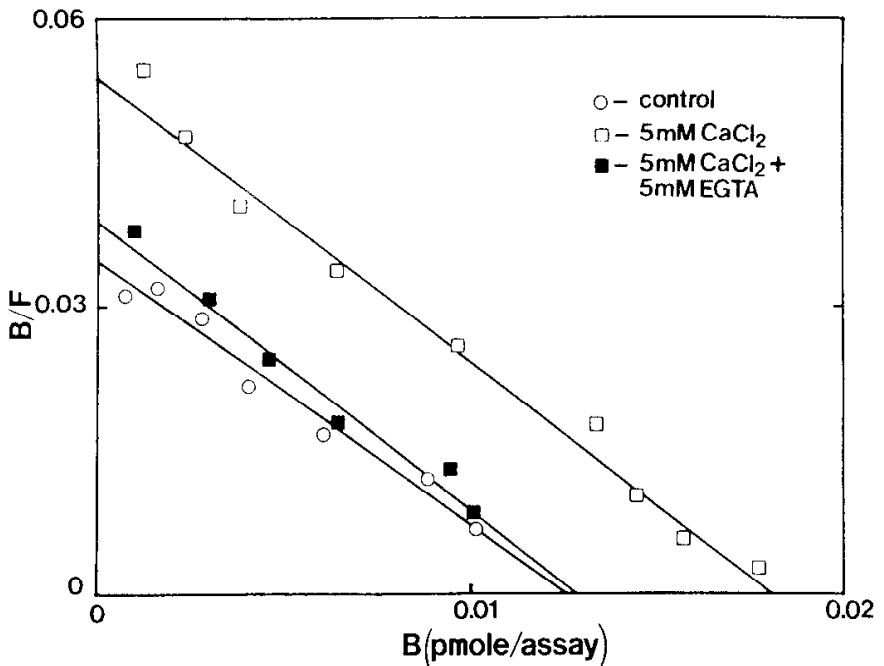

Figure 4. Saturation analysis $\left[{ }^{3} \mathrm{H}\right] \mathrm{FNZ}$ binding to soluble type 2 benzodiazepine receptors in the absence $(O)$ and presence of $5 \mathrm{mM} \mathrm{CaCl}_{2}(\square)$ or $5 \mathrm{mM} \mathrm{CaCl} \mathrm{m}_{2}$ plus 5 mM EGTA ( $\square$ ). The binding of [ $\left.{ }^{3} \mathrm{H}\right] \mathrm{FNZ}$ to type 1 receptors was unaffected by divalent cations at any concentration. Receptor binding was assayed at $0^{\circ} \mathrm{C}$ as described in the legend to Figure 1. The experiment was replicated twice with variations less than $20 \%$.

calcium and GABA must exert their actions through different mechanisms via separate sites. Calcium enhancement is additive to GABA stimulation (Fig. 5). Furthermore, GABA enhancement appears to be augmented by calcium and increases with increasing concentration of calcium. The interaction between GABA and calcium is distinctly different from the interaction between chloride and calcium (Fig. 5).

In the presence of either $0.1 \mathrm{M}$ or $0.025 \mathrm{M}$ chloride, GABA still increases type 2 receptor binding indicating additivity of chloride and GABA effects. The potency of GABA in stimulating receptor binding is increased 5 fold in the presence of chloride, with half-maximal stimulation $\left(\mathrm{EC}_{50}\right.$ ) values for GABA of $1.5 \mu \mathrm{M}$ and $0.3 \mu \mathrm{M}$ in the absence and presence of $0.1 \mathrm{M}$ chloride, respectively. These $\mathrm{EC}_{50}$ values were calculated by log-probit analysis using six to eight GABA concentrations with $\mathrm{EC}_{50}$ values varying less than $20 \%$ in three independent determinations. Unlike chloride, calcium does not change the potency of GABA in stimulating type 2 receptor binding. This binding supports separate mechanisms for chloride and calcium stimulation.

Effects of agents influencing oxidation-reduction on modulation of solubilized benzodiazepine receptors by $G A B A$ and ions. Some divalent cations influence many oxidative-reductive reactions, especially those involving sulfhydryl groups. To ascertain whether such actions might play a role in the influence of ions on solubilized benzodiazepine receptors, we explored the effects of $\beta$ mercaptoethanol, dithionitrobenzoic acid (DTNB), and ascorbic acid on the ability of GABA, chloride, and divalent cations to regulate solubilized benzodiazepine receptors (Table V). All of the stimulatory effects of GABA, chloride, and calcium are similar in the presence or absence of $\beta$-mercaptoethanol, DTNB, and ascorbic acid in the concentrations used in this study. The failure of $\beta$-mercaptoethanol and DTNB to alter the actions of divalent cations, chloride, or GABA suggests that oxidation-reduction effects in sulfhydryl groups of benzodiazepine receptors are not crucial. Similarly, the oxidative state of the receptor appears to be unimportant for its modulation by GABA and ions, since enhancement of the receptor activity is not affected by the addition of ascorbic acid.

Differential protection of soluble benzodiazepine receptor binding from heat inactivation of divalent cations, chloride, and GABA. GABA, chloride, phosphate, and calcium ions have been shown to protect benzodiazepine receptor binding in intact brain membranes from heat inactivation (Squires et al., 1978; Gavish and Snyder, 1980; Squires, 1981; Squires and Saederup, 1982). To ascertain whether these agents augment $\left[{ }^{3} \mathrm{H}\right] \mathrm{FNZ}$ binding by solubilized type 1 and type 2 receptors at the same sites as those that mediate protection from heat inactivation, we conducted heat inactivation experiments (Fig. 7). GABA clearly protects both type 1 and type 2 soluble receptors from heat inactivation, which fits with its ability to enhance binding of both receptors. In contrast, calcium and chloride protect type 2 but not type 1 receptors from heat inactivation, which goes along with their ability to stimulate binding of soluble type 2 but not type 1 receptors. These findings further support the notion that type 2 but not type 1 receptors possess specific recognition sites for divalent cations and chloride whereas both receptors have recognition sites for GABA. The results also indicate that GABA recognition sites on both subtypes of benzodiazepine receptors and the divalent cation and chloride sites on type 2 receptors probably exist in fairly close proximity to the benzodiazepine recognition site in the soluble state.

\section{Discussion}

In the present study we have evaluated two physically separated solubilized benzodiazepine receptors designated type 1 and type 2 . Earlier we showed that treating brain membranes with Triton X-100 solubilizes only a fixed and limited proportion of benzodiazepine-binding sites despite repeated treatment with high concentrations of Triton X-100, whereas the residual receptor binding can be completely solubilized by a combination of Triton X-100 and $1 \mathrm{M} \mathrm{NaCl}$ (Lo et al., 1982a). The

TABLE V

Effect of redox reagents on $G A B A$ and ion modulation of soluble benzodiazepine receptors

Dialyzed receptor extracts were preincubated with $1 \mathrm{mM} \beta$-mercaptoethanol, $1 \mathrm{~mm}$ DTNB, $0.5 \%$ ascorbic acid, or buffer for $30 \mathrm{~min}$ at $0^{\circ} \mathrm{C}$ prior to addition of $10 \mu \mathrm{M}$ GABA, $0.1 \mathrm{M} \mathrm{NaCl}$ or $1 \mathrm{mM} \mathrm{CaCl} 2$, and receptor activity was assayed with $\left[{ }^{3} \mathrm{H}\right] \mathrm{FNZ}$. The values shown are means of the three separate experiments which varied by less than $25 \%$.

\begin{tabular}{|c|c|c|c|c|c|c|}
\hline \multirow{3}{*}{ Treatment } & \multicolumn{6}{|c|}{$\left[{ }^{3} \mathrm{H}\right] \mathrm{FNZ}$ Binding (\% Control) } \\
\hline & \multicolumn{2}{|c|}{$10^{-5} \mathrm{M}$ GABA } & \multicolumn{2}{|c|}{$0.1 \mathrm{M} \mathrm{Cl}$} & \multicolumn{2}{|c|}{$1 \mathrm{mM} \mathrm{Ca}^{2+}$} \\
\hline & Type 1 & Type 2 & Type 1 & Type 2 & Type 1 & Type 2 \\
\hline Contro & 139 & 125 & 103 & 162 & 100 & 165 \\
\hline $\begin{array}{l}1 \mathrm{mM} \beta \text {-Mercapto- } \\
\text { ethanol }\end{array}$ & 130 & 125 & 96 & 159 & 89 & 166 \\
\hline $1 \mathrm{mM}$ DTNB & 120 & 126 & 90 & 160 & 85 & 150 \\
\hline $0.5 \%$ Ascorbic acid & 138 & 128 & 90 & 151 & 86 & 155 \\
\hline
\end{tabular}




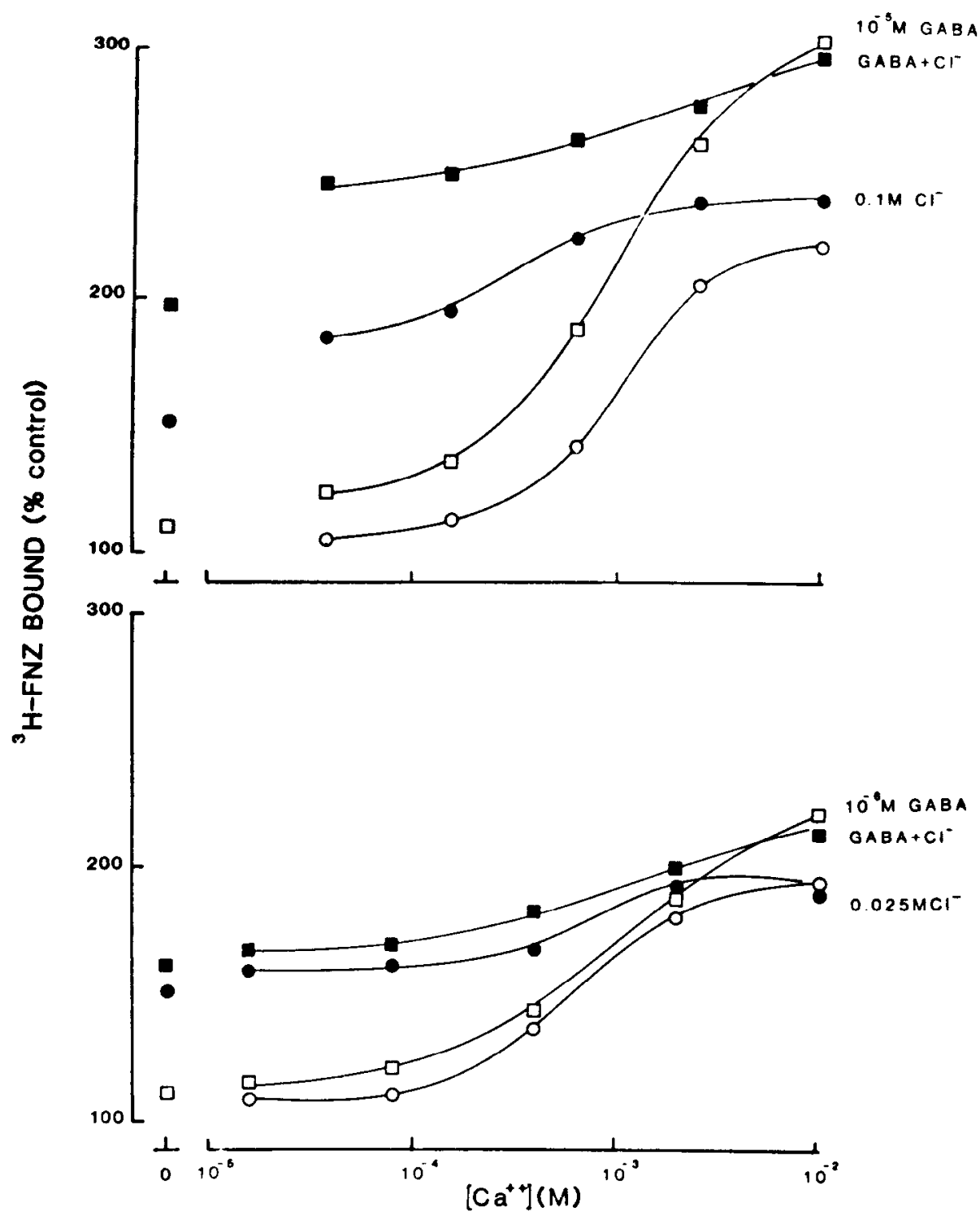

Figure 5. Modulation of soluble type 2 receptor by calcium. The data show the effects of adding concentrations of GABA and chloride, which gives maximal (upper) or submaximal (lower) stimulation when added alone. Receptor activity is shown in different calcium concentrations alone $(\mathrm{O})$, or with $\mathrm{NaCl}(\odot)$, GABA $(\square)$, and GABA plus $\mathrm{NaCl}(\mathrm{U})$. Receptor activity is expressed as percentage of $\left[{ }^{3} \mathrm{H}\right] \mathrm{FNZ}$ bound in controls in buffer alone. Values shown are the mean of three experiments which varied less than $20 \%$.

receptors solubilized by Triton $\mathrm{X}-100$ alone are more highly concentrated in the hippocampus and corpus striatum than in the cerebellum, whereas receptors solubilized only with salt plus Triton X-100 are more highly concentrated in the cerebellum. The triazolopyridazine, CL218872, and $\beta$-carboline esters, which are thought to be selective for type I receptors, have greater potency at the sites that require salt plus Triton X-100 to solubilize them than at those receptors readily solubilized with Triton X-100. Accordingly, we designated the sites solubilized with Triton X-100 alone as type 2 receptors and those that require Triton $\mathrm{X}-100$ plus $\mathrm{NaCl}$ for solubilization as type 1 receptors. This distinction has been supported by our recent autoradiographic studies (Lo et al., 1983). Using differential displacement by CL218872,
Young et al. (1981) observed different microscopic distributions of pharmacologially defined type 1 and type 2 receptors. We have compared the autoradiographic localization of benzodiazepine receptors before and after treatment with detergents (Lo et al., 1983). The distribution of detergent-resistant receptors corresponds closely to that of pharmacologically defined type 1 benzodiazepine receptors, further supporting the notion that type 1 receptors are those less readily solubilized by detergent.

The major finding of the present study is the differential regulation of solubilized type 1 and type 2 receptors by various ions. In the membrane-bound state benzodiazepine receptor binding is enhanced by a variety of anions with relative activities that parallel somewhat 


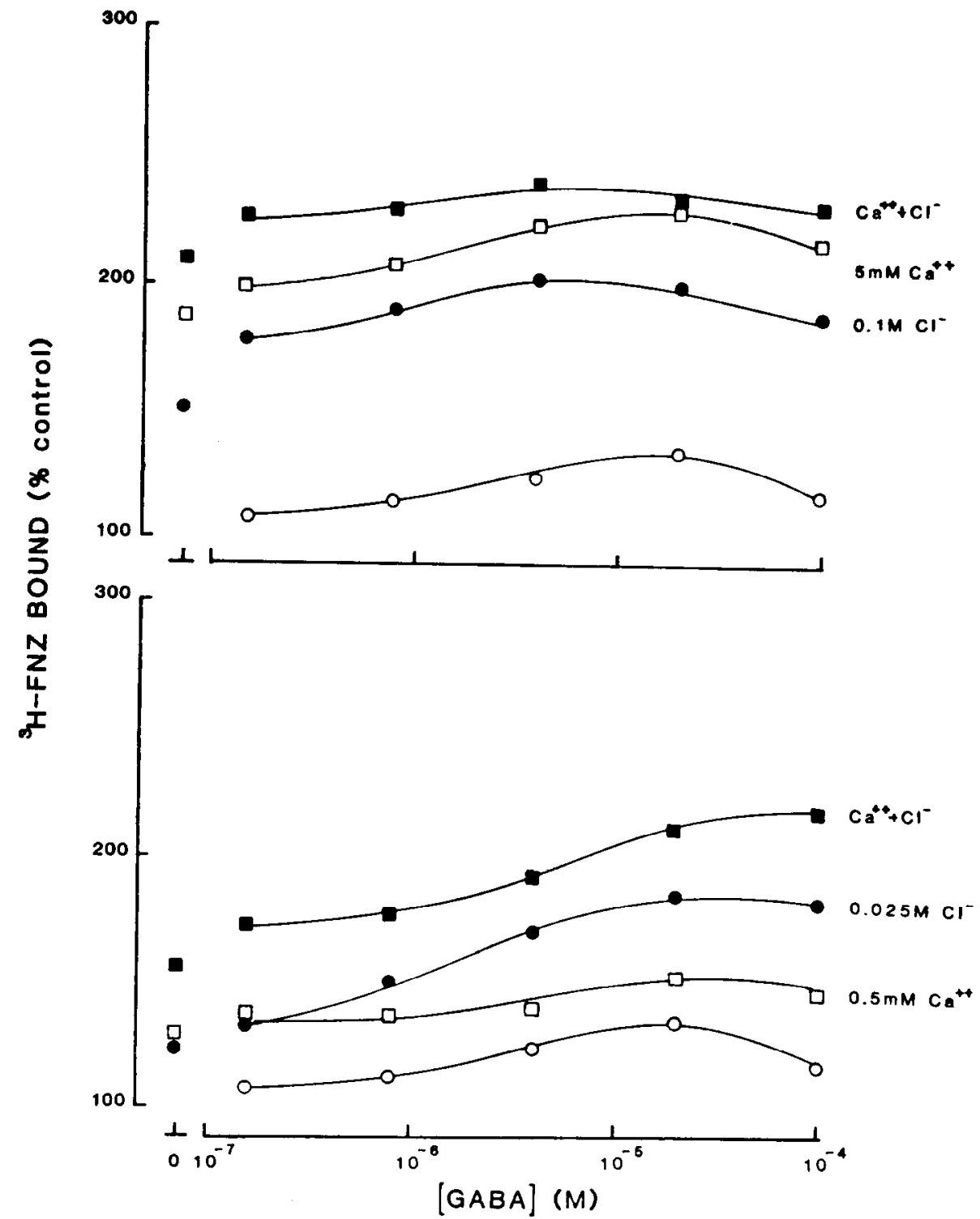

Figure 6. Modulation of soluble type 2 receptor binding by GABA. Effects of adding concentrations of chloride and calcium, which gives maximal (upper) and submaximal (lower) stimulation when added alone. Receptor activity, expressed as percentage of control, as shown for type 2 receptors at different GABA concentrations alone (O) or with $\mathrm{NaCl}(\boldsymbol{O}), \mathrm{CaCl}_{2}(\square)$, and $\mathrm{NaCl}$ plus $\mathrm{CaCl}_{2}(\mathbf{\square})$. Values shown are means of three separate experiments which varied less than $20 \%$.

their effects in reversing inhibitory postsynaptic potentials in spinal cord and hippocampus, perhaps reflecting an association with chloride synaptic channels (Costa et al., 1979). Although the ratio of type 1 and type 2 receptors varies in different brain regions, all regions evaluated thus far possess both subtypes of receptors so that, using intact membrane preparation, it is difficult to ascertain rigorously whether anion effects involve predominantly one or the other receptor subtype. By differential detergent extraction we can physically separate type 1 and type 2 receptors and have observed that chloride stimulation of binding in the absence of GABA and divalent cations occurs only with type 2 receptors. Anion specificity is somewhat different from specificity in the membrane-bound state, since it is apparent only with chloride and bromide and to some extent with iodide. This indicates that the site for anion modulation in type 2 receptors is not the putative chloride channel suggested by Costa et al. (1979). However, we cannot rule out the possibility that anions, in addition to modulating the benzodiazepine receptor, could interact with the GABA receptor and the barbiturate-binding site or with the putative chloride channel in its lipid environment in the membrane state.

In order to deduce whether chloride stimulation in membrane-bound benzodiazepine receptor is exclusively at type 2 receptor sites, we have used a concentration of CL218827 to displace $\left[{ }^{3} \mathrm{H}\right] \mathrm{FNZ}$ binding to type 1 receptor sites in washed native hippocampal membranes. In this manner, we show that chloride stimulation in native membranes is attributed to type 2 and not type 1 receptor sites. 'The mechanism of anion-induced affinity increase 


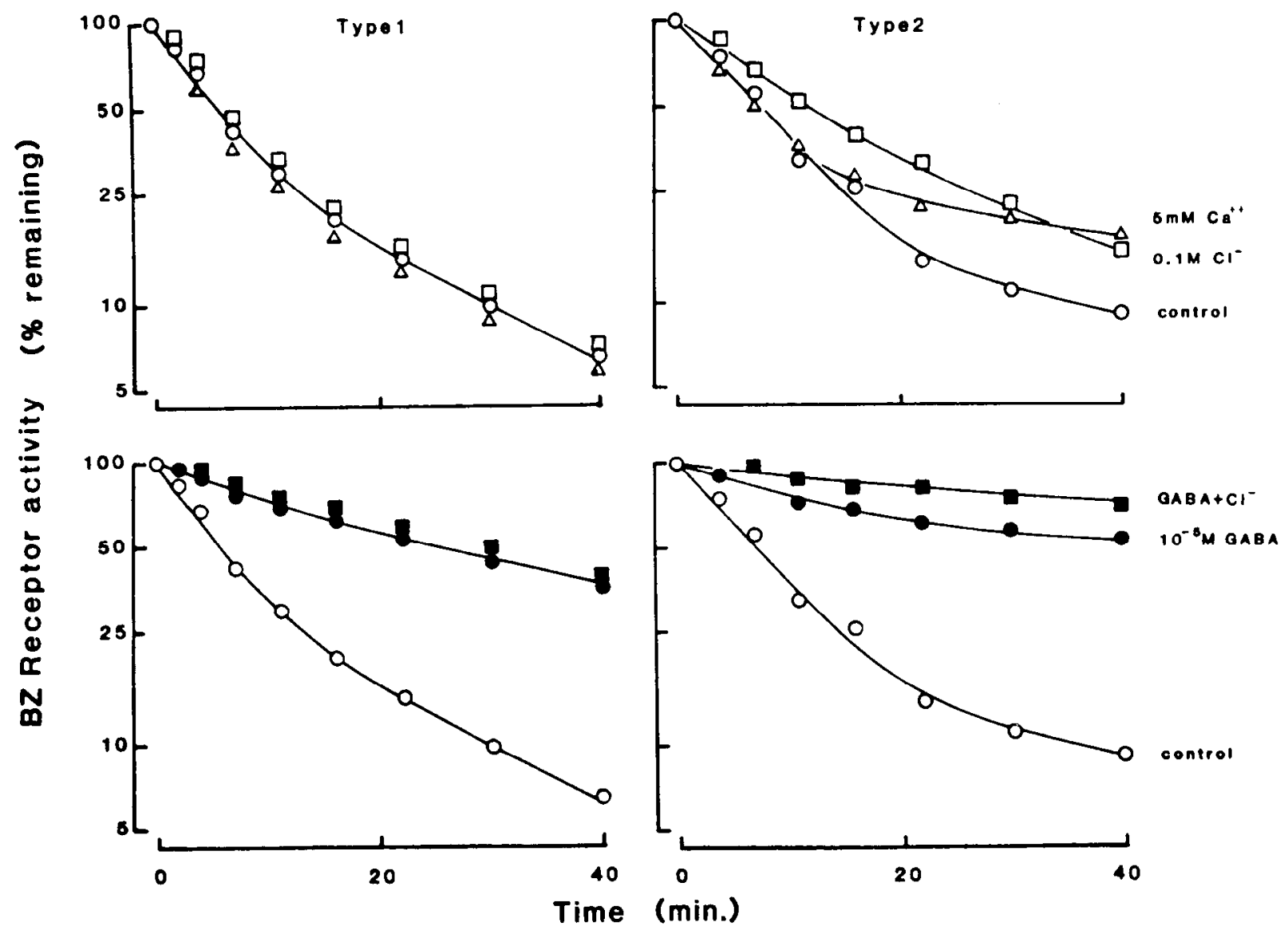

Figure 7. Protection of soluble type 1 and type 2 receptors from heat inactivation. Soluble receptors prepared from cow brain

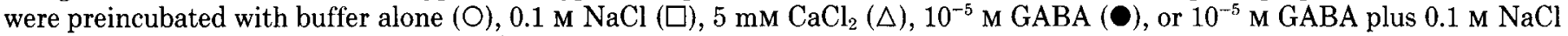
(G) at $0^{\circ} \mathrm{C}$ for $30 \mathrm{~min}$, then at $60^{\circ} \mathrm{C}$ for different times up to $40 \mathrm{~min}$. Receptor activity was measured by incubation with $0.8 \mathrm{nM}$ $\left[{ }^{3} \mathrm{H}\right] \mathrm{FNZ}$ in the presence of $0.1 \mathrm{M} \mathrm{NaCl}, 10^{-5} \mathrm{M} \mathrm{GABA}$, and $5 \mathrm{mM} \mathrm{CaCl}_{2}$ for $1 \mathrm{hr}$ at $0^{\circ} \mathrm{C}$ followed by precipitation and filtration. The results shown are expressed as percentage of receptor activity in samples not treated at $60^{\circ} \mathrm{C}$ but otherwise assayed as above. Values shown are means of three separate experiments which varied less than $20 \%$.

in type 2 receptor is difficult to explain in physical terms; it is possible that anions (like GABA) exert their actions through an anion recognition site on or near the benzodiazepine-binding site. Increases in receptor $B_{\max }$ caused by anions could be due to augmentation of trace amounts of cations present in the experiments. Such increases in the number of receptor sites could be accounted for by ion-induced conversion of low affinity sites not detectable by present binding techniques to high affinity states. In the membrane state anions have been reported to increase both the receptor affinity (Costa et al., 1979) and $B_{\max }$ (Squires et al., 1978). We find that anions increase type 2 receptor binding by a combination of increase in affinity and $B_{\max }$.

The significance of the divalent cation effect on solubilized type 2 receptors is unclear. For numerous receptors, agonist-binding activity is enhanced by divalent cations, which is thought to involve interactions with GTP-binding sites (Bird and Maguire, 1978; Williams et al., 1978; Rodbell, 1980). For some of these receptors the divalent cations vary in potency, with manganese often being most active. The similar potency of many divalent cations at type 2 receptors may indicate a different type of action, especially as no effect of guanine nucleotides on benzodiazepine receptors has yet been described or detected in our laboratory (M. M. S. Lo and S. H. Snyder, unpublished observations).

Thus the physiologic rule of the anion and divalent cation effects on type 2 receptors is unclear. The fact that these effects occur at physiologic concentrations of chloride and calcium suggests that they may be involved in the pharmacologic actions of benzodiazepines. If so, then these ionic influences would be relevant to actions mediated via type 2 and not type 1 receptors. This selectivity may provide a valuable probe for discriminating the different roles of the two receptor subtypes.

\section{References}

Asno, T., and N. Ogasawara (1981) Chloride-dependent stimulation of GABA and benzodiazepine receptor binding by pentobarbital. Brain Res. 225: 212-216.

Bird, S. J., and M. E. Maguire (1978) The agonist-specific effect of magnesium ion on binding by $\beta$-adrenergic receptors in S49 lymphoma cells. J. Biol. Chem. 253: 8826-8834.

Costa, T., D. Rodbard, and C. B. Pert (1979) Is the benzodiazepine receptor coupled to a chloride anion channel? Nature 277: 315-317.

Ennd, S. J., and S. H. Snyder (1977) Influences of ions, enzymes and detergents on $\gamma$-aminobutyric acid receptor binding in snypatic membranes of rat brain. Mol. Pharmacol. 13: 442453. 
Ehlert, F. J., W. R. Roeske, and H. I. Yamamura (1981) Multiple benzodiazepine receptors and their regulation by $\alpha$ aminobutyric acid. Life Sci. 29: 235-248.

Gavish, M., and S. H. Snyder (1980) Benzodiazepine recognition sites on GABA receptors. Nature 287: 651-652.

Gavish, M., and S. H. Snyder (1981) $\gamma$-Aminobutyric acid and benzodiazepine receptors: Copurification and characterization. Proc. Natl. Acad. Sci. U. S. A. 78: 1939-1942.

Gavish, M., R. S. L. Chang, and S. H. Snyder (1979) Solubilization of histamine $\mathrm{H}_{1}$, GABA and benzodiazepine receptors. Life Sci. 25: 783-790.

Klepner, C. A., A. S. Lippa, D. I. Benson, M. C. Sano, and B. Beer (1979) Resolution of two biochemically and pharmacologically distinct benzodiazepine receptors. Pharmacol. Biochem. Behav. 11: 457-462.

Leeb-Lundberg, F., A. Snowman, and R. W. Olson (1980) Barbiturate sites are coupled to benzodiazepine receptors. Proc. Natl. Acad. Sci. U. S. A. 77: 7468-7472.

Lo, M. M. S., S. M. Strittmatter, and S. H. Snyder (1982a) Physical separation and characterization of two types of benzodiazepine receptors. Proc. Natl. Acad. Sci. U. S. A. 79: 680-684.

Lo, M. M. S., R. R. Trifiletti, and S. H. Snyder (1982b) Physical separation and characterization of two central benzodiazepine receptors. In Pharmacology of Benzodiazepines, E. Usdin, P. Skolnick, J. Tallman, D. Greenblatt, and S. M. Paul, eds., pp. 165-173, Macmillan Publishing Co., Inc., New York.

Lo, M. M. S., D. L. Niehoff, M. J. Kuhar, and S. H. Snyder (1983) Autoradiographic differentiation of multiple benzodiazepine receptors by detergent solubilization and pharmacological specificity. Neurosci. Lett., in press.

Mackerer, C. R., and R. L. Kochman (1978) Effect of cations and anions on the binding of $\left[{ }^{3} \mathrm{H}\right]$ diazepam to rat brain. Proc. Soc. Exp. Biol. Med. 158: 393-397.

Martin, I. L., and J. M. Candy (1978) Facilitation of benzodiazepine binding by sodium chloride and GABA. J. Neuropharmacol. 17: 993-998.

Muller, W. E., and S. H. Snyder (1978) Strychnine binding associated with synaptic glycine receptors in rat spinal cord membranes: Ionic influences. Brain Res. 147: 107-116.

Niehoff, D. L., R. D. Mashal, W. D. Horst, R. A. O'Brien, J. M. Palacios, and M. J. Kuhar (1982) Binding of a radiolabeled triazolopyridazine to a subtype of benzodiazepine receptors in rat cerebellum. J. Pharmacol. Exp. Ther. 221: 670675.

Nielsen, M., and C. Braestrup (1980) Ethyl- $\beta$-carboline-3-carboxylate shows differential benzodiazepine receptor interaction. Nature 286: 606-607.

Rodbell, M. (1980) The role of hormone receptors and GTPregulatory proteins in membrane transduction. Nature 284 : 17-22.

Sieghart, W., and M. Karobath (1980) Molecular heterogeneity of benzodiazepine receptors. Nature 286: 285-287.

Snyder, S. H., and R. R. Goodman (1980) Multiple neurotransmitter receptors. J. Neurochem. 35: 5-15.

Squires, R. F. (1981) GABA receptors regulate the affinities of anions required for brain specific benzodiazepine binding. Adv. Biochem. Psychopharmacol. 26: 129-138.

Squires, R. F., and E. Saederup (1982) $\alpha$-Aminobutyric acid receptors modulate cation binding sites coupled to independent benzodiazepine-picrotoxin acid anion binding sites. Mol. Pharmacol. 22: 327-334.

Squires, R. F., D. I. Benson, C. Braestrup, J. Coupet, C. A. Klepner, V. Myer, and B. Beer (1978) Some properties of brain specific benzodiazepine receptors: New evidence for multiple receptors. Pharmacol. Biochem. Behav. 10: 825-830.

Williams, L. T., D. Mullikin, and R. J. Lefkowitz (1978) Magnesium dependence of agonist binding to adenylate cyclasecoupled hormone receptors. J. Biol. Chem. 253: 2984-2989.

Young, A. B., and S. H. Snyder (1974) The glycine synaptic receptor: Evidence that strychnine binding is associated with the ionic conductance mechanism. Proc. Natl. Acad. Sci. U. S. A. 71: 4002-4005.

Young, W. S., III, D. Niehoff, M. J. Kuhar, B. Beer, and A. S. Lippa (1981) Multiple benzodiazepine receptors: Localization by light microscope radiohistochemistry. J. Pharmacol. Exp. Ther. 216: 425-430. 